\title{
The Heterogeneity of the Abiotic and Biotic Components of Techno-Ecosystems: View from Space and from The Earth
}

\author{
Prof. Protasov A.A., \\ Institute of Hydrobiology of NAS of Ukraine, Kyiv, Ukraine \\ Prof. Sophia Barinova,
}

Institute of Evolution, University of Haifa, Mount Carmel, 199 Abba

Khoushi Ave., Haifa, Israel

MSc. Novoselova T.N.,

Institute of Hydrobiology of NAS of Ukraine, Kyiv, Ukraine

Buseva Zh.F., PhD,

The State Scientific and Practical Center of Belarus

for Biological Resources of the NAS

Tomchenko O.V., PhD,

State institution "Scientific Centre for Aerospace Research of the Earth of the Institute of Geological Science of the NAS of Ukraine

Sylaieva A.A., PhD,

Institute of Hydrobiology of NAS of Ukraine, Kyiv, Ukraine

Lubskiy N.S., PhD,

State institution "Scientific Centre for Aerospace Research of the Earth of the Institute of Geological Science of the NAS of Ukraine

\section{Prof. Semenchenko V.P,}

Sysova E.A., PhD,

The State Scientific and Practical Center of Belarus

for Biological Resources of the NAS

Doi: 10.19044/esj.2019.v15n3p423～URL:http://dx.doi.org/10.19044/esj.2019.v15n3p423

\begin{abstract}
The article discusses the use of different methods to assess the spatial structure of the biotic and abiotic component of the techno-ecosystems of cooling ponds of thermal and nuclear power plants in Belarus and Ukraine. Field studies provide point information on the parameters of biotic and abiotic variables, whereas statistical mapping and remote sensing methods makes it possible to generalize visualization and provides a holistic picture of the spatial heterogeneity of conditions and distribution of biota. Spatial changes in cooling ponds are mainly determined by hydrodynamic conditions in the
\end{abstract}


pond and the presence of anthropogenic flow of cooling water. Studies have shown that the distribution of quantitative indicators of plankton in the surface layer in the Khmelnitsky NPP cooling pond was mostly determined by the position of individual stations and sections of the pond surface relative to manmade technical and wind circulation flows. In contrary, thermal conditions had the greatest influence on the characteristics of the plankton distribution in the Lukomskoye Lake - cooling pond of Lukomlskaya TPP.

Keywords: Phytoplankton, Zooplankton, Lakes, Ecological mapping, Remote sensing, Nuclear Power Plants, Thermal Power Plants, Technoecosystem

\section{Introduction}

Freshwater Heterogeneity of habitat conditions in water bodies, as well as heterogeneity of biotic elements of ecosystems can be considered at various levels. For example, the allotment of littoral and profundal zones of water bodies is based on a significant difference in habitat conditions of hydrobionts in the coastal area and in the open part of the reservoir. However, the littoral itself is a fairly complex habitat; in particular, higher aquatic plants of different eco-morph groups are a factor that increases heterogeneity.

It is shown that certain discreteness of biotic communities can be formed even in the absence of an obvious heterogeneity of environmental conditions (Zhirkov et al., 2010). Well-known are vertical stratification of zooplankton (Kiselev, 1980), mosaic, and patchiness of benthic communities (Townsend, 1989). Techno-ecosystems of reservoirs that are used as coolers for thermal and nuclear power plants have a great heterogeneity in both the biotope structure and biotic communities (Protasov, 2011, 2013, 2014). This is due to the design features of cooling systems, as well as with the discharge of heated waters, the formation of wind and technogenic flows.

A complex structure of hydrodynamic flows, thermal fields, and circulation are formed. Regarding the pelagic groups of hydrobionts of these water bodies have certain heterogeneity (Barinova et al., 2017a). Distribution of different types of bottom, different technogenic solid substrates besides the thermal and hydrodynamic regime are influence on the heterogeneity of benthic and periphyton communities

The aim of this work was to identify the nature of heterogeneity of conditions and distribution of hydrobiont groups in water bodies, which are associated with cooling systems of power plants.

\section{Material and Methods}

Studies were carried out on two cooling ponds. The Khmelnitsky NPP (KhNPP) cooling pond is an artificial reservoir with an area of $17 \mathrm{~km}^{2}$, an 
average depth of $6 \mathrm{~m}$, was commissioned in 1987. The entrance to the intake channel, as well as the discharge of heated water from the discharge channel, are located in the eastern part of the reservoir. The KhNPP cooling pond was invided in 2004 by zebra mussel (Dreissena polymorpha Pall.) that has maximal biomass in 2008 and then slowly decreased. Its biofouling of the technical constructions of the canals has created giant problem for the KhNPP functionality and development of other organisms in the cooling pool ecosystem (Barinova et al., 2017b). Detailed characteristics are presented in (Protasov, 2011). Studies of this water techno-ecosystem have been conducted for about 20 years' (Protasov et al., 2017a).

The cooling pond of Lukomlskaya TPP is a lake in the north-eastern part of Belarus (Lake Lukomskoye), on the bank of which in its northeastern part there is a power plant with intake and discharge channels. The lake has an area of about $33 \mathrm{~km}^{2}$, and used as a cooler since 1964 (Mitrahovich et al., 2008).

Both water bodies do not have special training wall to direct the heated water, therefore, the distribution of the temperature fields depends essentially on the wind currents.

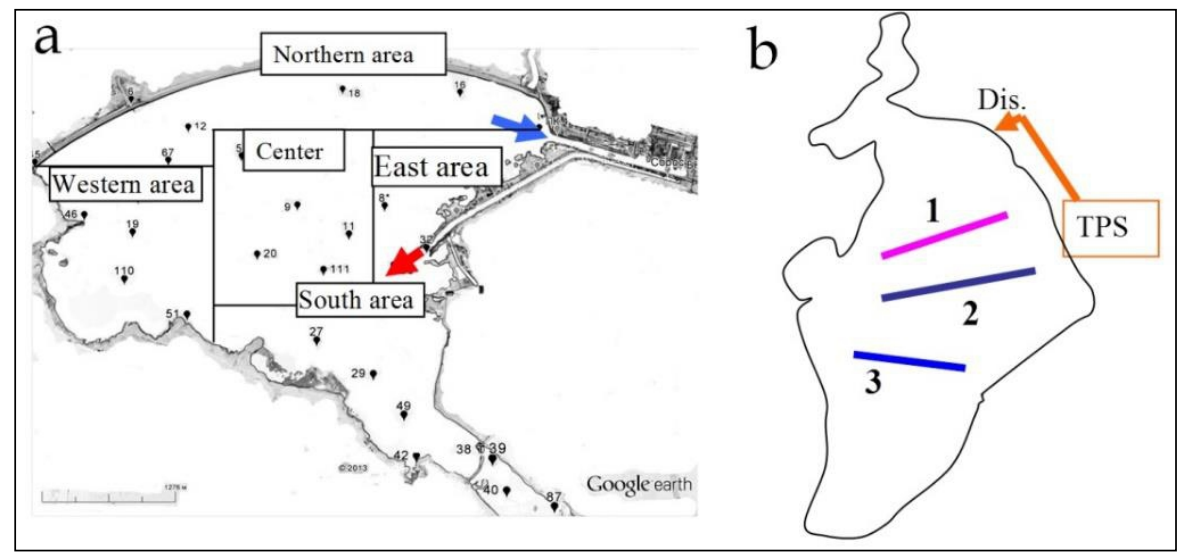

Figure 1. Map of location of areas and sampling points with input (blue arrow), output (red arrow) of hot water from KhNPP to the cooling pond (a), map of location of the sampling transects $(1,2,3)$ Lukomskoye lake (b) Dis - exit point of the discharge channel, TPS location of Thermal Power Station

Current analysis is represented the results of research of the KhNPP cooling pond for certain years in the period from 2006 to 2015 and Lukomlskaya TPP cooling pond for 2015 and 2017. Map of location of areas and sampling points in the KhNPP cooling pond is shown in Figure 1a. Sampling on Lake Lukomskoye was carried out on three transects (Figure 1b). Four stations were equally distributed at each transect. The sampling, fixation and processing of hydrobiological samples were carried out according to generally accepted procedures (Methodology, 2006). 
The following physicochemical parameters of water were recorded during the sampling in both reservoirs: temperature $\left({ }^{\circ} \mathrm{C}\right)$, transparency (Secki disk, $\mathrm{m})$, and depth (m).

Samples of phytoplankton with a volume of $0.5 \mathrm{dm}^{3}$ were taken in the pelagic part of the KhNPP cooling pond using a Ruttner's bathometer from the surface horizon (0.3-0.5 m). In August 2012, 11 phytoplankton samples were taken in the KNPP cooling pond, in September 2015 - 12.

Twelve integral samples of phytoplankton were taken using a Ruttner's batometer (volume 2 liters) in Lake Lukomskoye in August 2015 and August 2017 from the following horizons: max depth - depth of transparency - half transparency depth - $1 \mathrm{~m}$ depth - surface. Phytoplankton samples were fixed with a $2 \%$ formaldehyde solution. Transportation of samples was carried out in ice box (Methodology, 2006; Shcherbak, 2006).

A fixed material was quantitatively recorded by direct counting in a Nageott chamber $\left(0.02 \mathrm{~cm}^{3}\right)$ using an MBI-3 microscope under magnification $\mathrm{x} 400$ and $\mathrm{x} 800$. The diatom species were studied under $\times 1000$ with Axio Amager A1 light microscope.

The modern taxonomy of algae taxa is given according to algaebase.org (Guiry, Guiry, 2018).

The calculation of algae abundance and biomass (thousand cells $\mathrm{dm}^{-3}$ or million cells $\mathrm{dm}^{-3}$ ) in each sample was made according (Topachevsky, Masyuk, 1984).

Average cell volumes and the stereometric method were used for calculation the phytoplankton biomass (Kumsare, 1963; Kuzmin, 1975).

Mathematical processing of the primary material was performed using the Waco application software package developed at the Institute of Hydrobiology of the National Academy of Sciences of Ukraine (Protasov et al., 1999).

Altogether 24 samples of zooplankton were taken in August 2015 and August 2017 field trips in Lake Lukomskoye. Crustacean zooplankton samples were obtained by vertical hauls using a tow net of $100 \mu \mathrm{m}$ mesh size ( $0.25 \mathrm{~m}$ diameter). Samples collection was performed at each station in 3 replicates. Samples were preserved with $4 \%$ formaldehyde and treated under a stereomicroscope to determine species composition.

For the analysis of the heterogeneity of zoobenthos, 8 samples were collected from the KhNPP cooling pond in October 20-21, 2016 on the depths 2.5-9.0 m, where bottom was represented by sands of varying degrees of siltation. Sampling was done by a bottom grabber; the sampling area was 0.01 $\mathrm{m}^{2}$. Benthic invertebrates were sorted under microscopes, identified to species level, and counted. 
To analyze the dynamic picture of the flows in the KhNPP cooling pond, a mathematical method of "full flows" was applied (Protasov, 2011; Timchenko et al., 2014).

The Shannon-Boltzmann entropy function was used to quantify the diversity of temperature conditions for the KhNPP cooling pond (Viktorov, 1986, Protasov, 2008). The values of the relative area of temperature fields with a similar temperature are used.

The Shannon diversity index was assessed by calculation of species diversity (Pesenko, 1982; Protasov, 2008). The similarity between the communities and the originality of the composition was determined by the method of Smirnov (Smirnov, 1969). The definition of similarity indexes according to Smirnov was carried out according to Smirnov (1969) and Pesenko (1982), the originality $t_{x x}$ was carried out by analyzing the frequency (occurrence or absence of a species) calculated for each list of species (CELS) at a given station.

The coefficient of variation (CV) was calculated by the equation 1 (Plokhinsky, 1970):

$\mathrm{CV}=(100 \sigma) / \mathrm{M}, \%$

Where: $\sigma$ is the standard deviation; $\mathrm{M}$ - arithmetic average.

Remote sensing satellite sensors that are provide 3-14 $\mu \mathrm{m}$ data have been widely used in the field of Earth remote sensing and allow the creation of products based on the detection of cells of intense thermal radiation (detection of forest fires, study of volcanic activity) or the formation of maps of the thermal field of low spatial resolution for the solution of meteorological problems.

The most commonly used longwave infrared data is the data acquired by Thermal Infrared Sensor (TIRS) mounted on Landsat-8 satellite, which provides radiance data in two bands: in 10.3-11.3 $\mu \mathrm{m}$ and 11.5-12.5 $\mu \mathrm{m}$. The temperature is determined from Planck's law (Tang, 2014) as:

$$
T=\frac{c_{2}}{\lambda \ln \left(\frac{\varepsilon(\lambda) c_{1}}{\lambda^{5} L_{s}}+1\right)},
$$

where $L_{s}-$ spectral radiance from the Earth's surface, estimated from calibrated and atmospherically corrected satellite longwave infrared data; $\varepsilon(\lambda)$ - spectral emissivity; $c_{1}=2 h c^{2}=1,191 \cdot 10^{-16} \mathrm{~W} \cdot \mathrm{m}^{2}$ and $c_{2}=\frac{h c}{k}=1,439 \cdot 10^{-}$ ${ }^{2} \mathrm{~m} \cdot \mathrm{K}$ - first and second Planck's constant; $\lambda$ - radiation wavelength.

Determination of the Earth's surfaces emissivity distribution using remote sensing data is performed by processing images of the visible and nearinfrared range, in particular by establishing of the relationship between emissivity the NDVI index distribution. The source of the visible and near- 
infrared data can be any satellite that able to provide it: Landsat-8, Sentinel-2 etc. The emissivity is a rather inert surface feature, and for its determination, it is possible to involve data obtained with some time interval in comparison with the data of the long-wavelength range. For large homogenous areas, like water surfaces, the common table-value can be used (water emissivity is $\approx$ 0.985). Most commonly, satellite remote sensing data is provided by USGS EarthExplorer web-service (https://earthexplorer.usgs.gov/).

Daily average wind speed was established for the mapping according to remote sensing data.

The study of the distribution of phytoplankton is possible with the use of remote sensing data, based on a specific empirical index - Normalized Relative Algoindex (NDAI) (Silkin, 2012). The NDAI is calculated as follows:

$$
N D A I=\frac{I_{G}+2 I_{N I R}-I_{B}-I_{R}}{I_{G}+2 I_{N I R}+I_{B}+I_{R}}+0.5,
$$

where $\mathrm{I}_{\mathrm{B}}, \mathrm{I}_{\mathrm{G}}, \mathrm{I}_{\mathrm{R}}, \mathrm{I}_{\mathrm{NIR}}$ - stand for the spectral reflectance measurements acquired in the blue, green, red (visible) and near-infrared regions, respectively.

Atmospheric noise and background radiation of water are minimized when calculating algoindex. Spectral characteristics of scattered and concentrated phytoplankton are taken into account. Values less than -0.5 correspond to minimum values of phytoplankton biomass; about 0 - low biomass of phytoplankton; more than 0.5 - the level of biomass during the "flowering" of water.

The methods for data analysis were used as comparative analysis of species richness and qualitative and quantitative data of hydrobionts as well as statistically generated maps of environmental and biological data in the Statistica 12.0 program (Barinova, 2017).

\section{Results}

\section{Features of hydrothermal and hydrodynamic regime of the Khmelnitsky NPP cooling pond}

From 6 to 9 million $\mathrm{m}^{3}$ of water, depending on the operating mode of the pumps passes into the cooling system per day when two power units are operating (Protasov, 2011). The thermal heterogeneity in the surface layer of the cooling pond is mainly determined by the currents of water, formed under the influence of wind and technogenic currents. Maps of the distribution of temperature fields obtained with the help of remote sensing, for different periods with winds of the main directions are shown in Figure 2.

So, at the western wind, which is most unfavorable for cooling function of cooling pond the flow of heated water is pressed to the eastern shore and along the shortest trajectory, is directed from the discharge channel 
to the intake one (Figure 2a). The most favorable for the cooling of discharge waters is the situation that is formed by the east wind (Figure 2 b). In contrary, the north wind presses the flow from the discharge channel to the southern part of the water body. In these conditions, the reservoir is actually divided into the cold northern and warm southern parts (Figure 2c). With the south wind, the mass of heated water is distributed from the diverting channel through the pond center to the dam in the northern part of the reservoir, when sufficiently cooled water enters the intake channel (Figure $2 \mathrm{~d}$ ).

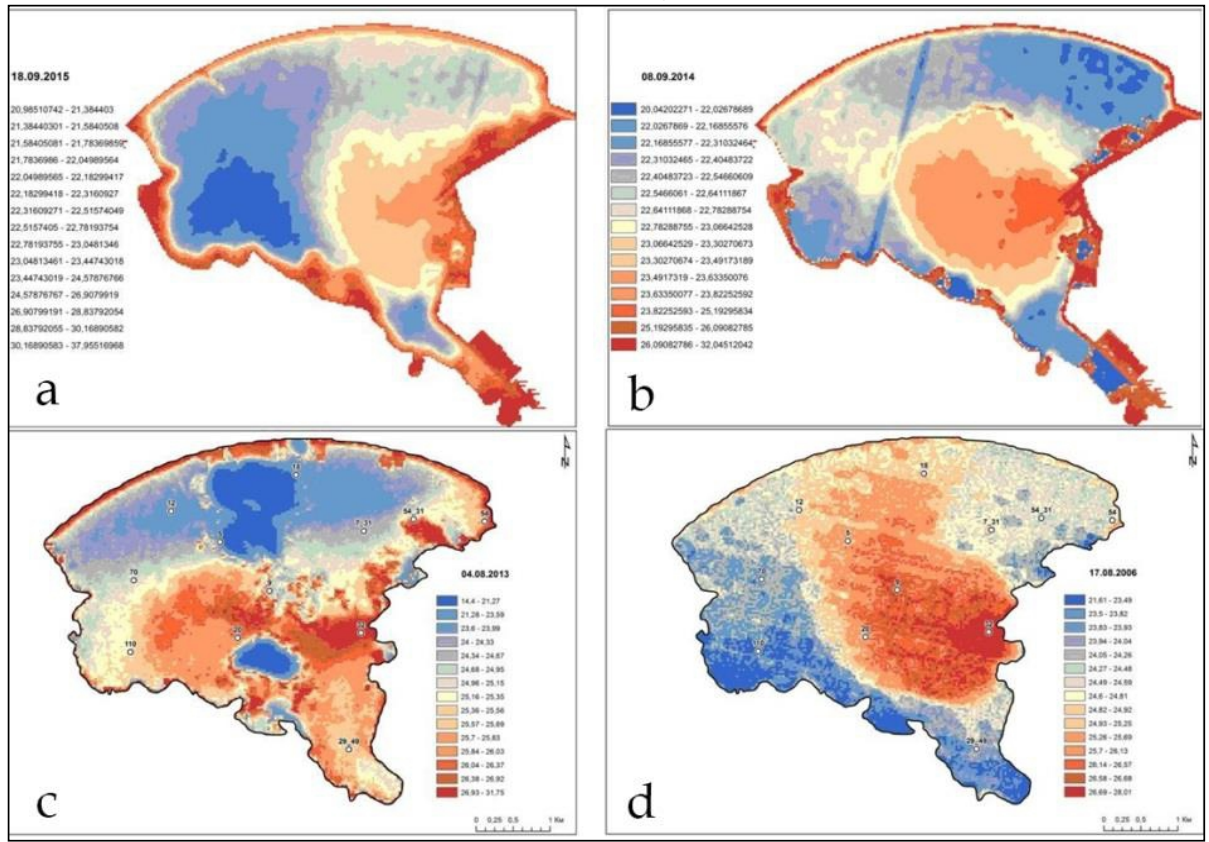

Figure 2. Distribution of temperature fields in the KhNPP cooling pond at the western, 3.7 $\mathrm{m} \mathrm{s}^{-1}$ (a), east, $1.1 \mathrm{~m} \mathrm{~s}^{-1}$ (b), northern, $1.3 \mathrm{~m} \mathrm{~s}^{-1}$ (c), and south, $3.2 \mathrm{~m} \mathrm{~s}^{-1}$ (d) wind directions (according to remote sensing data)

Analysis of four real meteorological situations has shown that very diverse temperature conditions are formed in the surface layer of the cooling pond. For the four main wind situations on the grid of stations where plankton samples were collected, the Shannon-Boltzmann index value (bit $/{ }^{\circ} \mathrm{C}$ ) was close to the maximum (Table 1). Values of evenness indicate that fields with different temperature levels did not differ significantly in area.

Table 1. Values of the Shannon-Boltzmann index for temperature at the wind of the main directions in the KhNPP cooling pond.

\begin{tabular}{|l|l|l|l|l|}
\hline Indices & north & south & west & east \\
\hline Shannon H' (Log Base 2), bit $/{ }^{\circ} \mathrm{C}$ & 3.582 & 3.584 & 3.579 & 3.583 \\
\hline Shannon Hmax (Log Base 2) & 3.585 & 3.585 & 3.585 & 3.585 \\
\hline
\end{tabular}


For all the illustrative value of the results of space imagery, it must be taken into account that we get a static picture, while the result at a given time is a derivative of many factors. This is a more or less stable result of the action of complex dynamic processes.

The dynamics of water masses is one of the leading factors of the functioning of water ecosystems and the creation of heterogeneous conditions in water bodies, especially in the pelagic zone. The results of modeling of the movement of water masses are in good agreement with the observed pattern of temperature distribution (Figure 3)

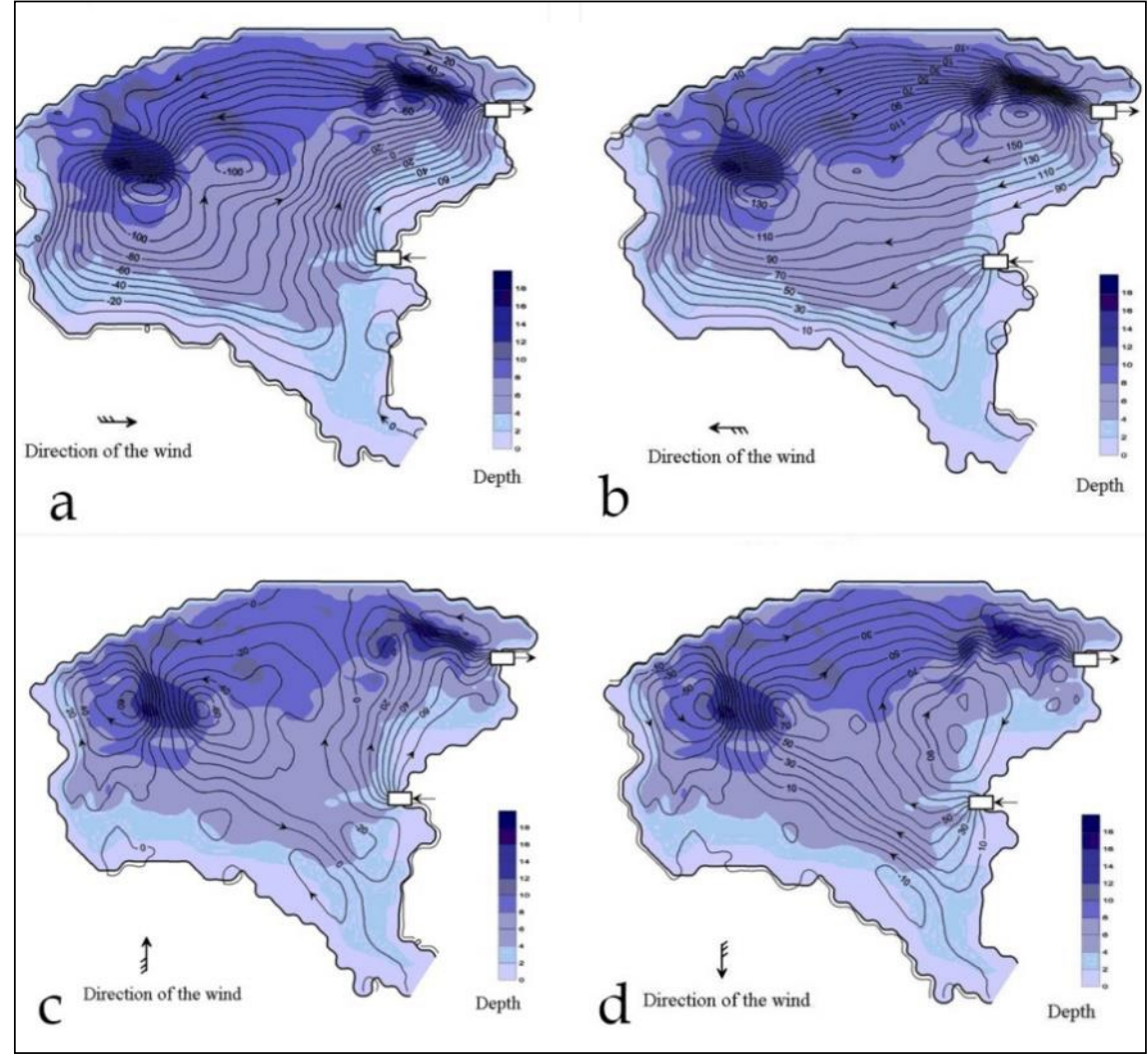

Figure 3. Flow diagram (flow functions, $\mathrm{m}^{3} \mathrm{~s}^{-1}$ ) in the KhNPP cooling pond with the operation of two units and a flow velocity of $3 \mathrm{~m} \mathrm{~s}^{-1}$ in wind conditions of the western (a), eastern (b), northern (c) and southern (d) directions according to Protasov (2011).

Thus, with the wind of the northern direction, the transit flow from the place of discharge partially captures the southern part, goes to the western one of the reservoir, and then, changing the direction to the eastern one, it wash up the northern shore and fall into the intake channel. That is, the temperature rises in the southern part of the reservoir, which is confirmed by the results of remote sensing (Figure 2c). In addition, in the eastern part of the reservoir 
between the discharge and intake channels a field with an anticyclonic moving of water masses is formed, and near the western shore - cyclonal (Figure 3c).

The distribution of phytoplankton by the water area of the KhNPP cooling pond depends on the complex of conditions that form in the reservoir such as, for example, temperature, and flow velocity. The main factors that influence the degree of its heterogeneity are wind flows (with non-operating units) and the NPP operation mode.

With the operation of one unit (September 11 of 2015) and the east wind with speed of up to $3.5 \mathrm{~m} \mathrm{~s}^{-1}$, the zone of the highest temperatures (upper then $26.5^{\circ} \mathrm{C}$ ) spread through the central part where the temperature already decreased by $4-5^{\circ} \mathrm{C}$ (Figure $4 \mathrm{a}$ ). In the surface horizon of the cooling pond, in the part remote from the outlet of the discharge channel, the average temperature was $20.8 \pm 0.2^{\circ} \mathrm{C}$. The Secchi transparency was ranged from 1.1 to $2.6 \mathrm{~m}$, the minimum and maximum values were recorded in the southern and northern areas, respectively, while in the rest of the water area the transparency changed insignificantly and averaged 2.21 $0.04 \mathrm{~m}$ (Figure 4b).

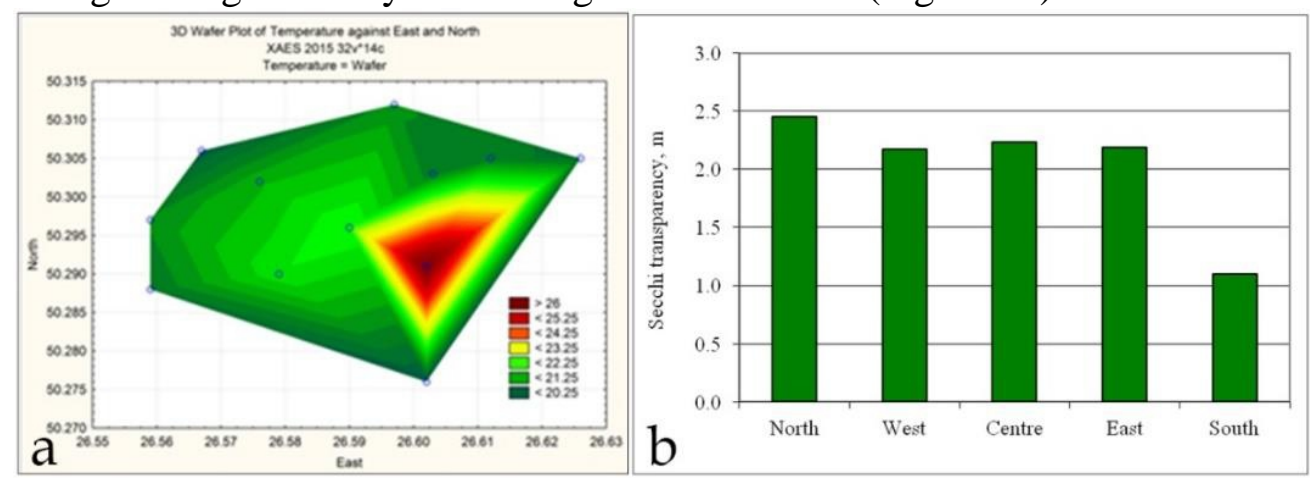

Figure 4. Temperature distribution, ${ }^{\circ} \mathrm{C}$ in the surface horizon (a) and the Secchi transparency, m (b) in KhNPP cooling pond, September 11 of 2015.

The phytoplankton taxonomic composition on the water area under these conditions was heterogeneous. The algae composition of the southern part of the cooling pond, not included in the circulation and wind flows, had the greatest originality (by the Smirnov index, $t_{x x}=154$ ). The originality of the remaining stations was estimated at an average of 91.0 \pm 11.7 . Local groups of phytoplankton at some stations had a greater similarity in the eastern and western areas.

Abundance fluctuations on the water area were significant: from 0.66 to 52.16 million cells $\mathrm{dm}^{-3}(\mathrm{CV}=128.22 \%)$. The minimum values were recorded in the central and western areas of the reservoir, the maximum values in the southern area (Figure 5a). The abundance value was mainly due to the development of cyanobacteria, whose share in the total abundance averaged $69.08 \pm 6.36 \%$. A positive relationship was established between the total 
abundance and abundance of cyanobacteria $(\mathrm{r}=0.99)$. The diatom fraction had an average of $15.12 \pm 3.80 \%$ abundance. The distribution of diatoms in the surface horizon was quite heterogeneous $(\mathrm{CV}=90.95 \%)$. The minimum abundance was noted in the center of the reservoir; the maximum was in the southern area. The green algae did not play a significant role $(7.69 \pm 2.50 \%$ of the total abundance) and their abundance also varied over a wide range $(\mathrm{CV}=141.40 \%)$.

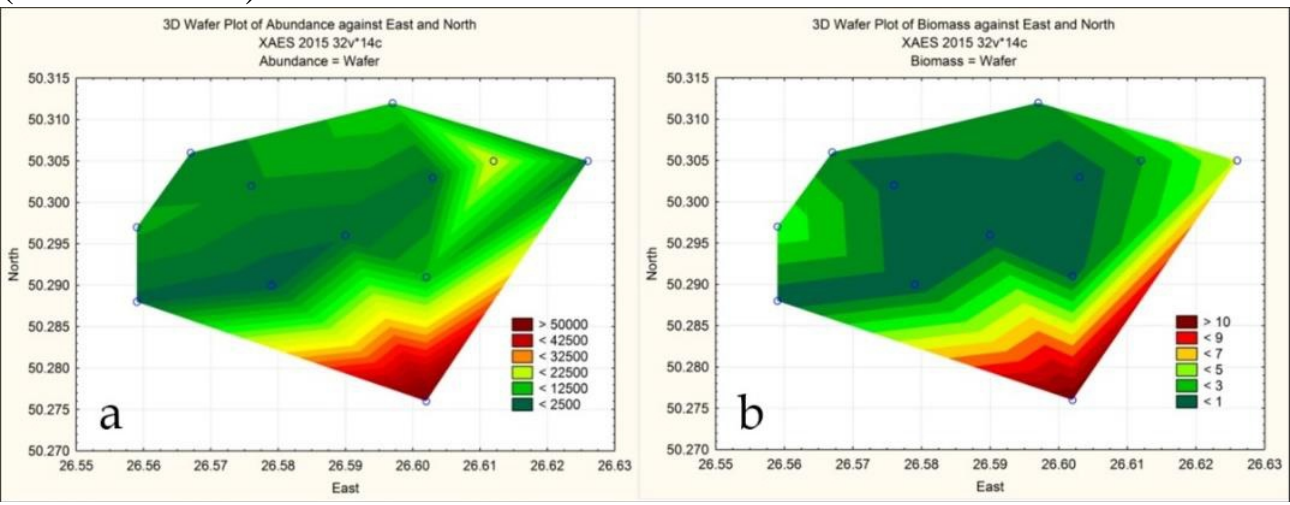

Figure 5. Distribution of phytoplankton abundance, thousand cells $\mathrm{dm}^{-3}$ (a) and phytoplankton biomass, $\mathrm{mg} \mathrm{dm}^{-3}$ (b), in KhNPP cooling pond, September 11 of 2015.

Biomass varied over a wide range: from 0.13 to $11.95 \mathrm{mg} \mathrm{dm}^{-3}$ $(\mathrm{CV}=147.47)$, the minimum was recorded in the center of the cooling pond, the maximum in the southern area (Figure $5 \mathrm{~b}$ ). The basis of the total biomass in most of the water area was formed by diatoms (46.19 $\pm 7.45 \%$ from total). The share of greens and cyanobacteria was $18.15 \pm 5.74$ and $16.86 \pm 4.36 \%$, respectively. The biomass of cyanobacteria was distributed similar to their abundance. Spatially minimum of the total biomass coincided with the minimum biomass of diatoms, and the maximum with the maximum biomass of green algae.

Interesting is the distribution of phytoplankton biomass in the circulation flow: it increased in the direction from the discharge channel to intake one (the character and direction of the flow passing through the eastern, central, western and again eastern areas is given in Figure $3 \mathrm{~b}$ ) due to the gradual increase in the flow the share of large-cell diatoms and the parallel reduction the share of smaller green and cyanobacteria. In the area of the intake channel, an increase by an order of magnitude of the average size of phytoplankton cells was observed in comparison with the outlet area of the discharge channel.

The diversity in abundance (according to the Shannon index) varied in the range from 0.83 to 3.02 bit/ind. The minimum values were associated with the overwhelming dominance $(87.48 \pm 2.88 \%)$ of cyanobacteria Microcystis aeruginosa (Kützing) Kützing and Aphanocapsa incerta (Lemmermann) 
G.Cronberg \& Komárek. These species were also dominated on the rest of the water area, but their share in the total abundance was lower $(50.68 \pm 5.87 \%)$ (Figure 6). An inverse relationship between the values of the Shannon index and the share of cyanobacteria in the total abundance $(\mathrm{r}=-0.86)$ was established.

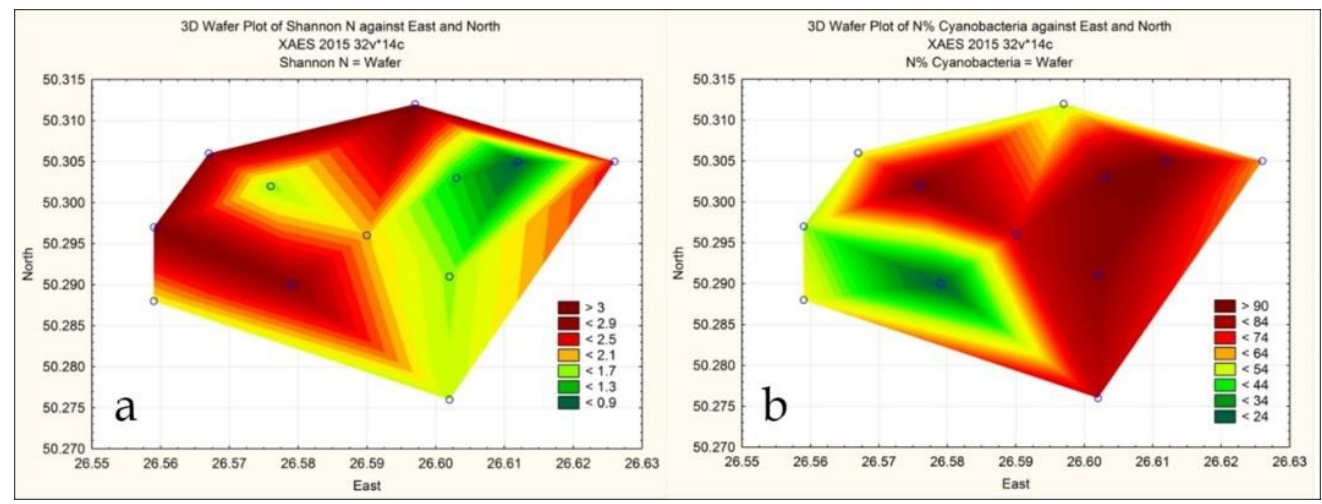

Figure 6. Distribution of diversity indicators in abundance (according Shannon index), bit/ind (a) and share of cyanobacteria in total abundance, \% (b) in KhNPP cooling pond,

September 11 of 2015.

The homogeneity of the biomass values structure increased in the direction toward the center of the cooling pond (Figure 7). Fluctuations in the Shannon index over the water area were $0.66-3.47 \mathrm{bit} / \mathrm{mg}$. The level of diversity in biomass was determined mainly by diatoms. The correlation coefficient of the values of the Shannon index from the share of diatoms in the total biomass was -0.73 .

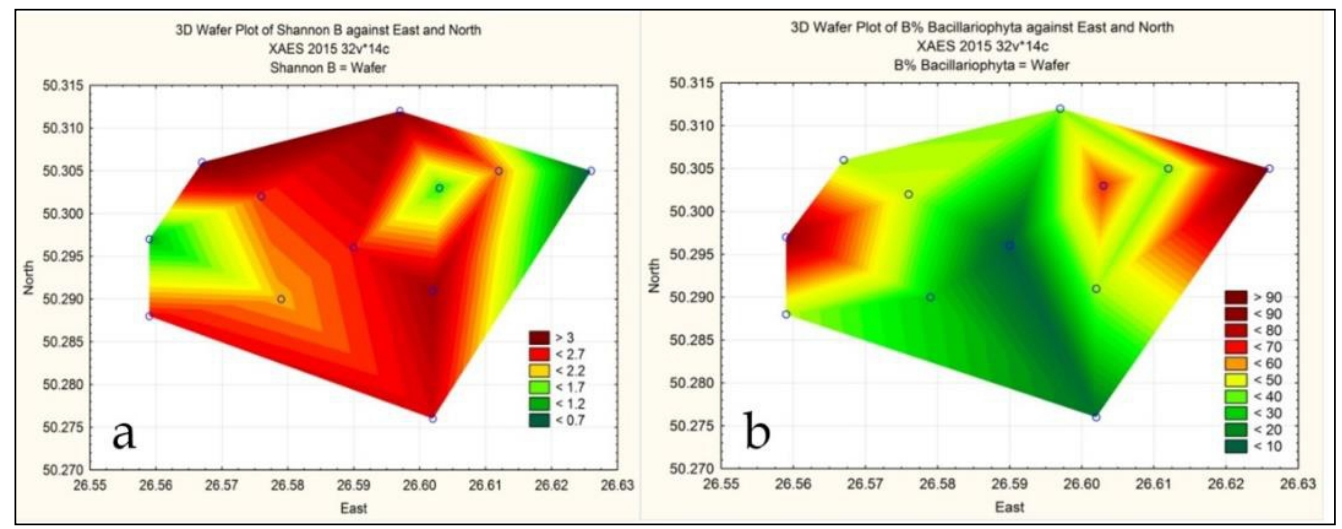

Figure 7. Distribution of Shannon index value bit/mg in biomass (a), and share of diatoms in total biomass, \% (b), KhNPP cooling pond, September 11, 2015.

During the research in phytoplankton, 11 species - temperature indicators were detected, of which 8 were indicators of temperate warm water, 1 - thermophilic, and 2 - eurytherms. Indicators of temperate warm water 
were noted in all areas of the reservoir, eurytherms - in the center and eastern area, thermophilic - only in the western (Table 2).

Table 2. Distribution of the number of algae temperature-indicative species by areas of the KhNPP cooling pond, September 11 of 2015.

\begin{tabular}{|l|l|l|l|l|l|}
\hline Temperature indicators & East & North & West & Centre & South \\
\hline temp & 4 & 5 & 3 & 4 & 3 \\
\hline warm & 0 & 0 & 1 & 1 & 0 \\
\hline eterm & 1 & 0 & 0 & 1 & 0 \\
\hline
\end{tabular}

Note: temp - indicators of temperate warm water, warm - thermophilic, eterm eurythermic.

Indicators of temperate warm water were noted at all the stations. Their list was formed by representatives of diatoms. The number of indicator species varied at individual stations from 1 to 5 (Figure 8). The temperate warm indicators are representing the "coolest" water from these three groups of algal species. So, its distribution show that northwestern and northeastern parts of cooling pool have lowermost temperature in the sampling date.

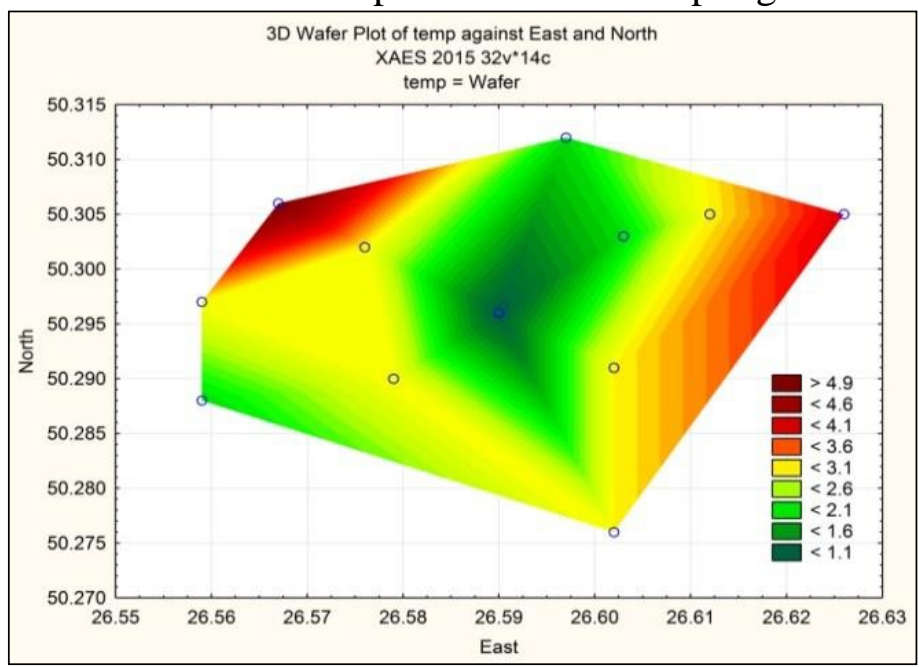

Figure 8. Distribution of the number of temperate warm water indicators by individual stations of KhNPP cooling pond in September 11 of 2015

\section{Algoindex and phytoplankton}

Remote sensing data are still little used in research and monitoring of the state of techno-ecosystems of power plants and often they need verification. To check the distribution of algoindex indicators in the KhNPP cooling pond, obtained from satellite observations, we compared them with the distribution of phytoplankton biomass obtained from field terrestrial research. 


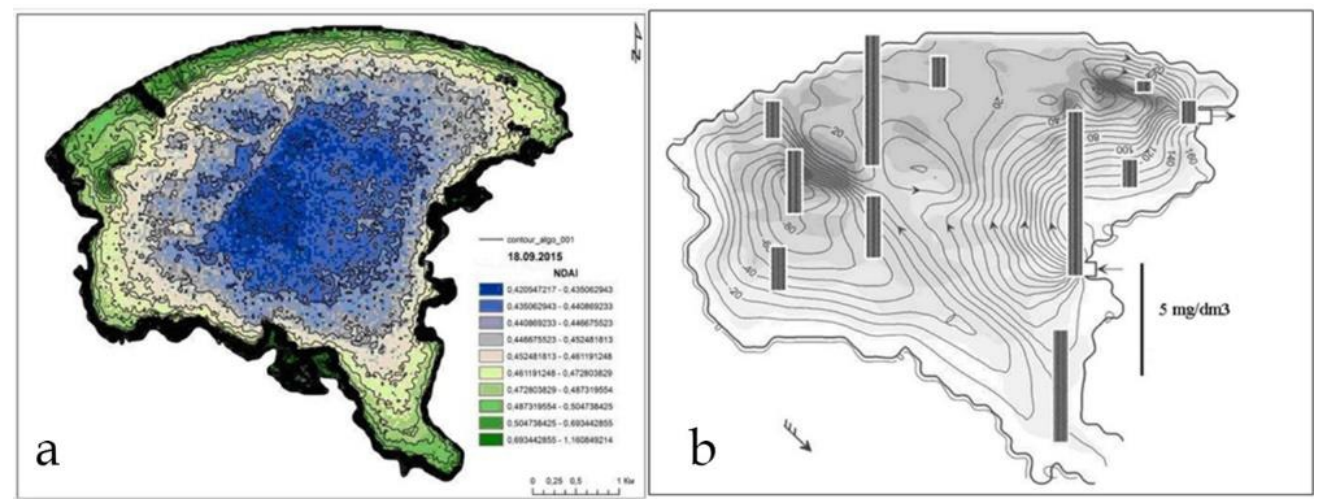

Figure 9. Distribution of the algoindex NDAI value in the KhNPP cooling pond, September,

18 of 2015 with the north-west direction of the wind (a) and phytoplankton biomass indicators in the KhNPP cooling pond (b), August, 29 of 2012 (wind directions, directions and consumption of wind flows are indicated).

During remote sensing period (September, 18 of 2015), in the region of the KhNPP cooling pond, a wind mainly north-western and western directions with an average speed of up to $5 \mathrm{~m} \mathrm{~s}^{-1}$ was observed. Under these conditions, the central part of the cooling pond was a zone with minimal index values (Figure 9a). Toward the periphery, the index values gradually increased and reached a maximum in the peripheral parts of the southern, western and northern areas, which in this direction of the wind are few involved in the circulation flows. The western part of the reservoir is quite clearly separated from the zone of minimum index values.

A significant heterogeneity was observed in the distribution of phytoplankton biomass in the water area of the cooling pond (Figure 9b). High values of biomass were recorded mainly on the peripheral part of the reservoir. Thus, the distribution of phytoplankton biomass in general terms corresponded to the distribution of the algoindex.

The zoobenthos of the KhNPP cooling pond also had a large heterogeneity, which is determined by the diversity of biotopes and habitat conditions. The taxonomic structure and distribution of indicators of the abundance of zoobenthos is mainly determined by the depth and type of bottom and, to a lesser extent, by temperature in the bottom layers of water. During the period of decreasing development of dreissenids after 2008 up to present, the zoobenthos biomass decreased, however, the heterogeneity of its distribution in different areas of the reservoir was remained - the maximum biomass values (in 2008) were 136 times higher than the minimum (in 2016) (Figure 10). So, now high biomass in shallow areas where samples were taken and also in the southern region was determined by the development of large Chironomidae. 


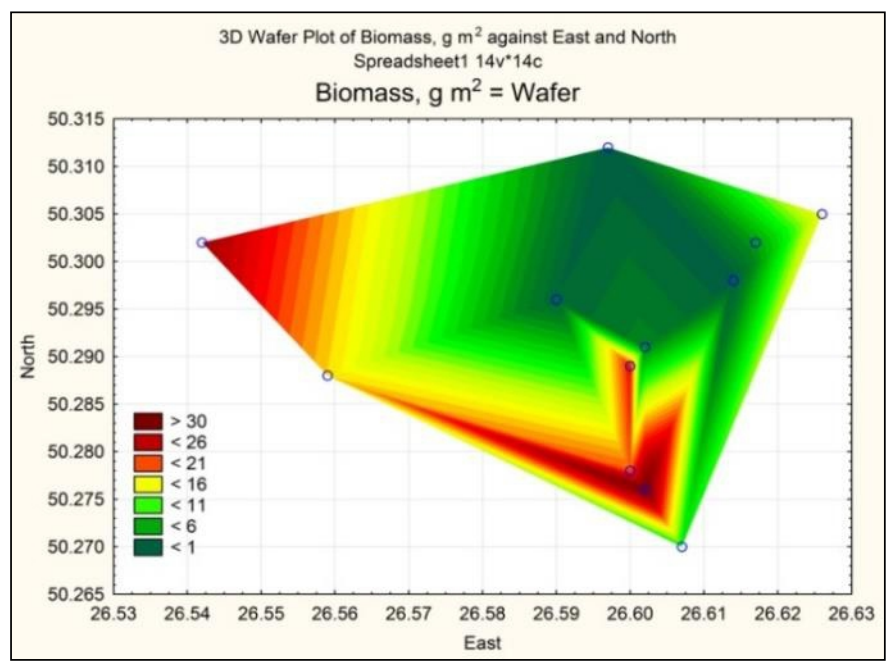

Figure 10. Distribution of the zoobenthos biomass, $\mathrm{g} \mathrm{dm}^{-2}$, KhNPP cooling pond, October 2015.

The number of taxa, as well as abundance and biomass decrease with increasing depth and siltation rate in reservoir. For example, the smallest biomass (on average for the period 1998, 1999, 2001 was at a depth of 5-6 m $\left(1.78 \mathrm{~g} \mathrm{~m}^{-2}\right)$, at other depths it was 2-16 times higher, increasing 176 times at a depth of $2-3 \mathrm{~m}$.

The use of information from satellites made it possible to estimate the change in the KhNPP cooling pond area when the water level fluctuates and there is no additional pumping in low-water years (2011, 2015, and 2016).

According to the results of the assessment in August 2015, the area of drained shallow waters amounted to $1.141 \mathrm{~km}^{2}$, and by 2016 it decreased to $0.627 \mathrm{~km}^{2}$, which is about $3-6 \%$ of the surface of the water body at the maximum water level.

\section{Distribution of temperature fields and biotic variables in the Lukomskoye Lake}

Surface flows in calm weather are directed from the northwestern part of the Lukomskoye Lake to the southern one, while backward flows create several cyclonal and anticyclonal circulations. With the southern wind, the high temperature zone is localized in the northern part of the lake (Figure 11). 


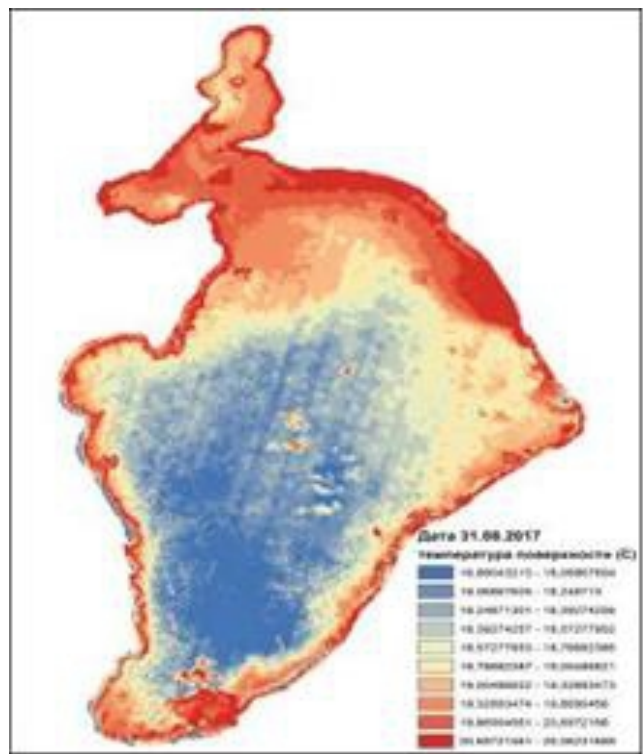

Figure 11. Temperature fields of the Lukomskoye Lake, August 30 of 2017 (the south wind) according to remote sensing data

With the north wind, the displacement of the heated water masses, and hence the temperature decrease, occurred from north to south, so the picture of the distribution of the temperature readings looked quite natural (Figure 12a). We can to use the temperature distribution data of 2015 and 2017 because the regime of discharge of heated waters of the Lukomskoye Lake was rather similar year by year (Mitrahovich et al., 2008).

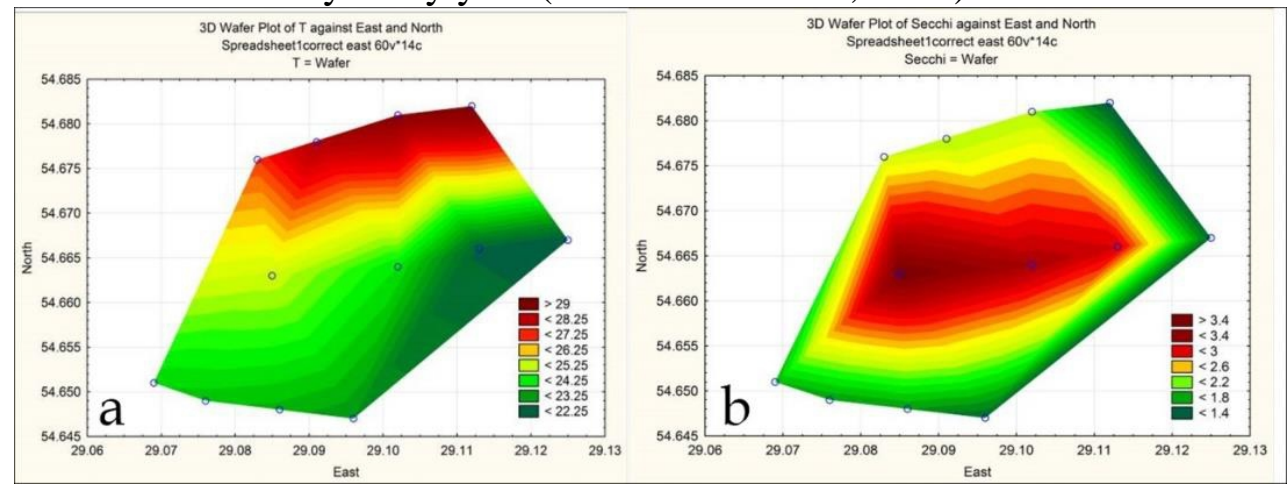

Figure 12. Water temperature distribution, ${ }^{\circ} \mathrm{C}$ in the surface horizon (a) and Secchi transparency, m (b) on three transects, the Lukomskoye Lake, September 12 of 2015.

However, the distribution of Secchi transparency was different (Figure $12 b)$.

The distribution of phytoplankton abundance and biomass indicators confirms the dependence on it transparency (Figures 13, 14), the biomass minimum is noted just on the intermediate transect (Figure 13b). 

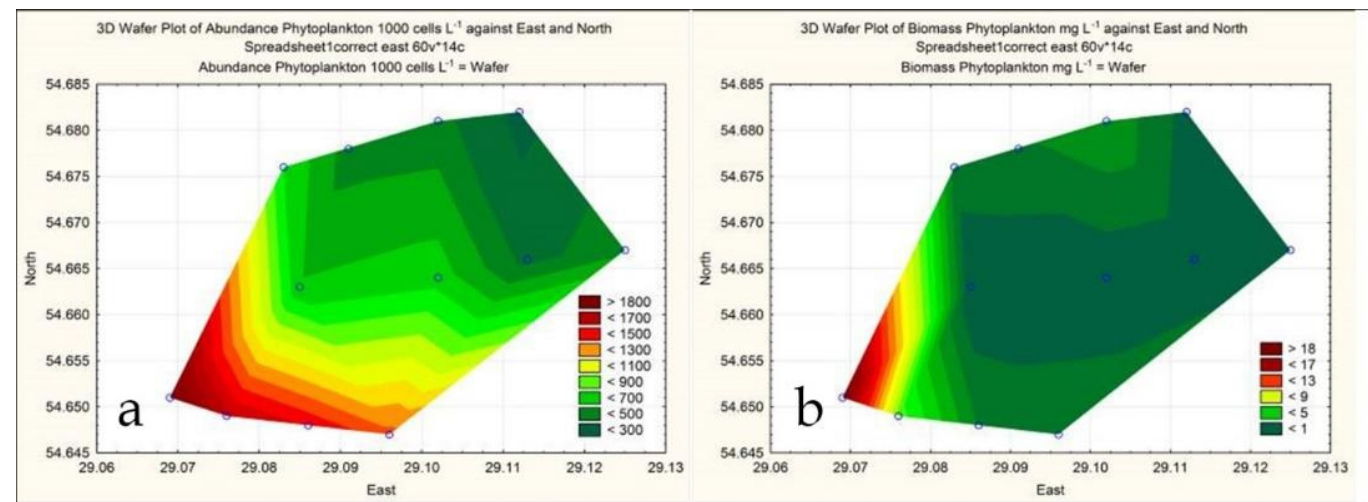

Figure 13. Distribution of phytoplankton abundance, thousand cells $\mathrm{dm}^{-3}$ (a) and phytoplankton biomass, $\mathrm{mg} \mathrm{dm}^{-3}$ (b) on three transects in the Lukomskoye Lake, September 12 of 2015

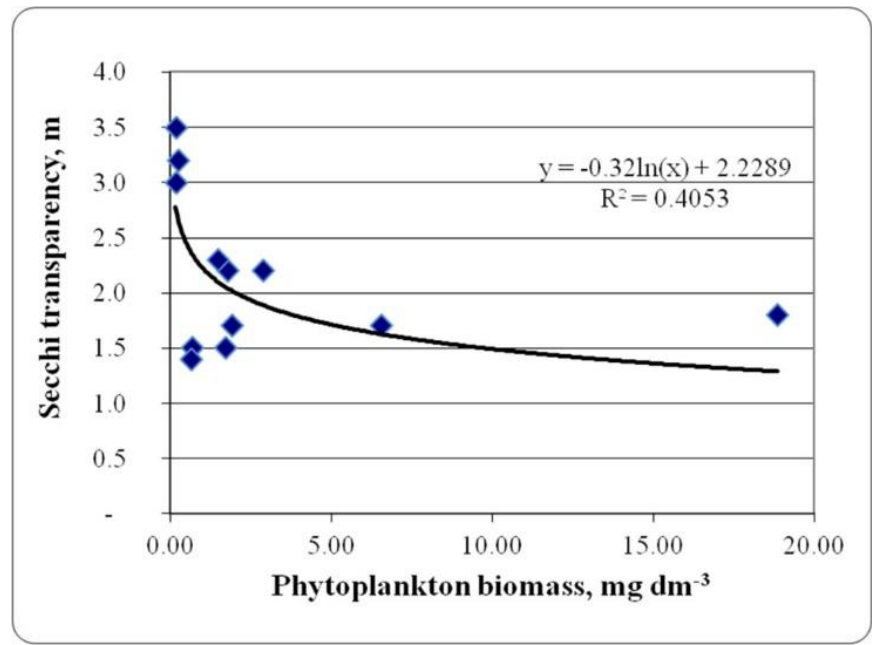

Figure 14. Dependence of Secchi transparency on phytoplankton biomass in the Lukomskoye Lake, September 12 of 2015

It should be noted that the dependence of Secchi transparency on phytoplankton biomass is exponential; algae with relatively low biomass have the greatest effect on change of transparency (Figure 14).

A fairly smooth transition of thermal conditions does not correspond to the same pattern for the biomass of phytoplankton. However, this does not apply equally to all groups of algae. A decrease in the shares of green and diatom algae occurred along the gradient of temperature decrease, while cyanobacteria - in the opposite direction (Figure 15). Thus, the picture of the distribution of the abundance indicators was generally determined by the distribution of cyanobacteria. 


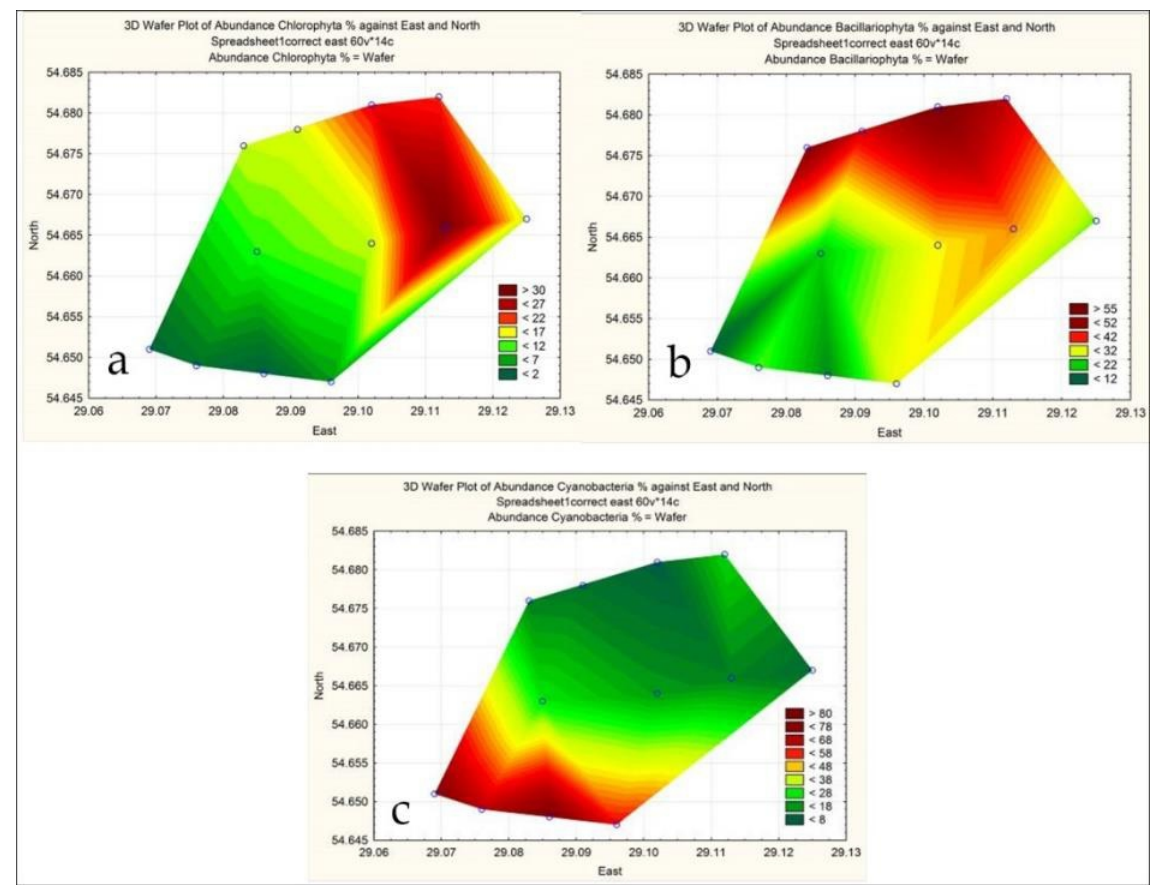

Figure 15. Distribution of abundance, \% of Chlorophyta (a), Bacyllariophyta (b) and Cyanobacteria (c) in the Lukomskoye Lake, September 12 of 2015

With regard to the distribution of phytoplankton biomass, the picture is looked somewhat different (Figure 16).

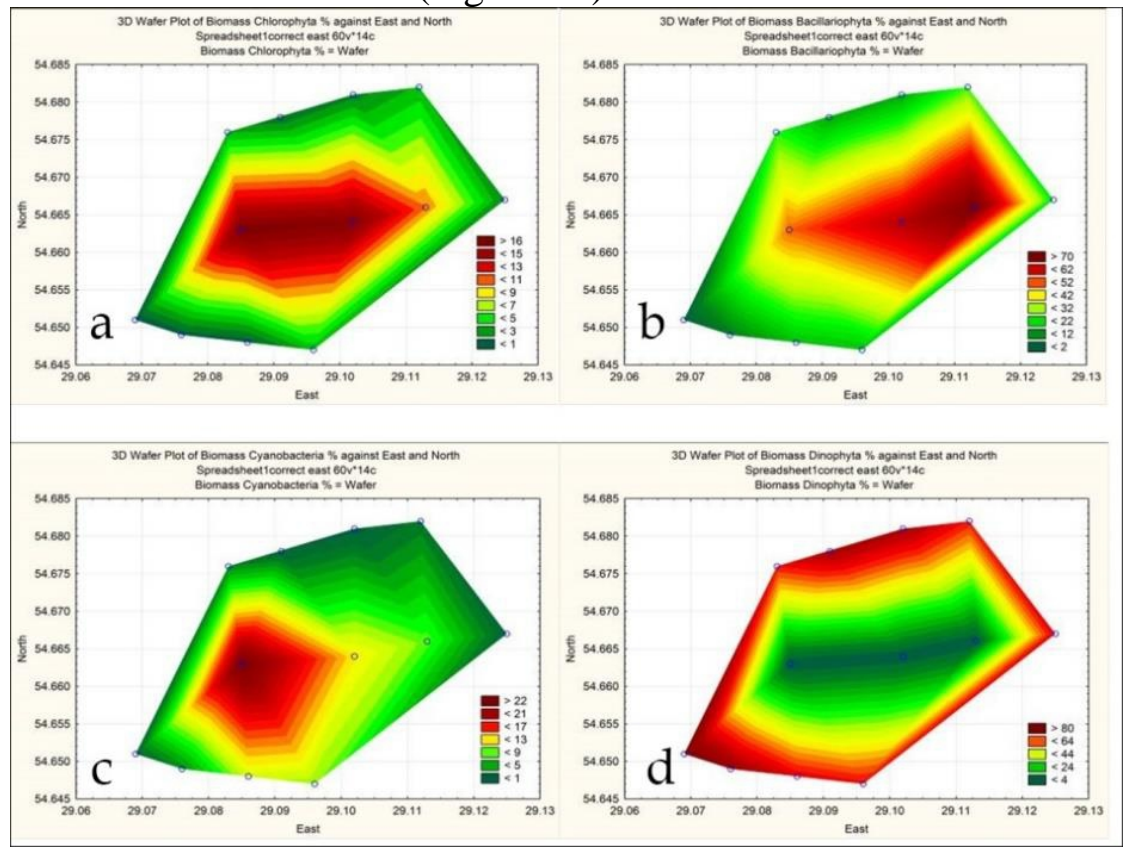

Figure 16. Distribution of biomass, \% of Chlorophyta (a), Bacyllariophyta (b), Cyanobacteria (c) and Miozoa (d) in the Lukomskoye Lake, September 12 of 2015 
Zooplankton of the Lukomskoye Lake. Studies of the spatial distribution of zooplankton were carried out in 2015 and 2017. Thermal conditions during these periods were somewhat different (Figures 11, 12a, 17a).
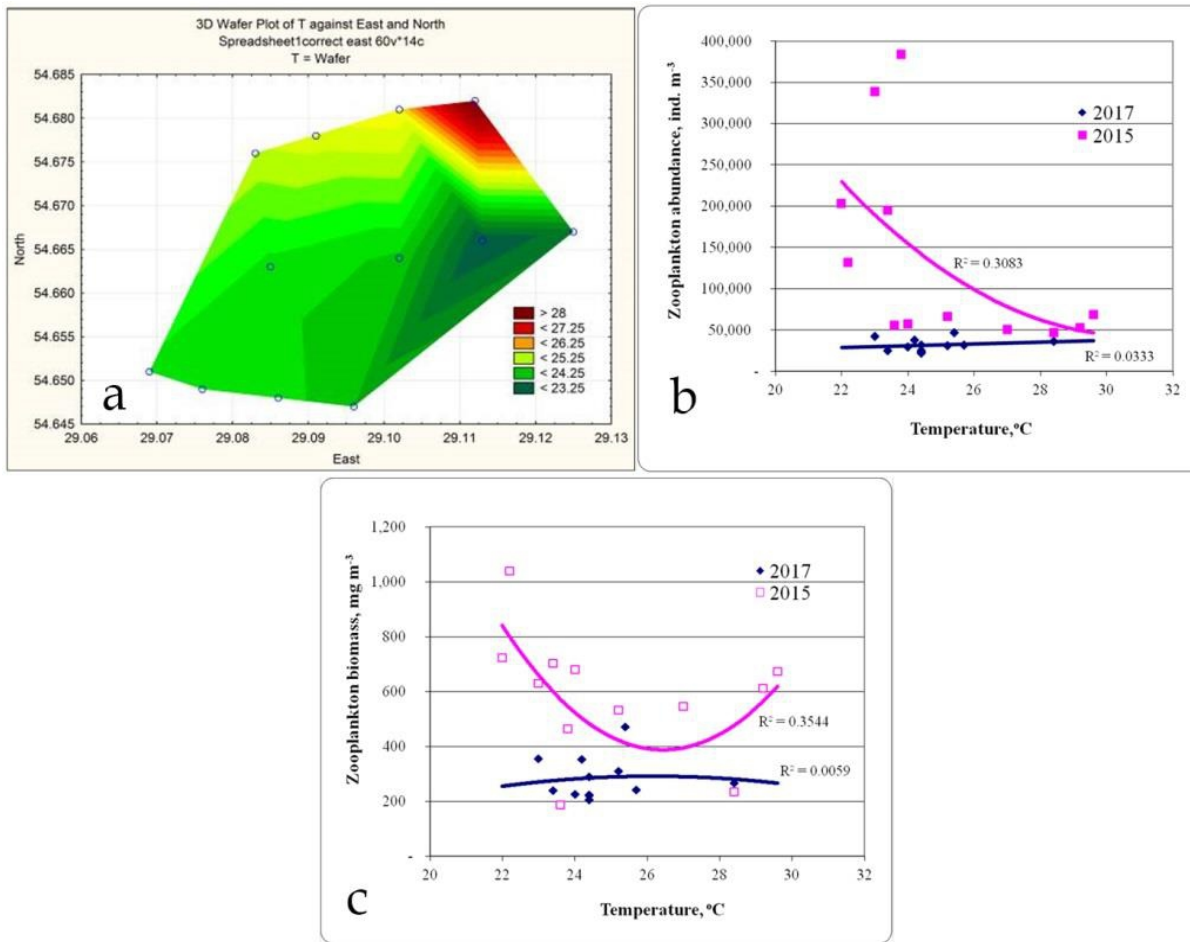

Figure 17. The distribution of water temperature in three transects in 2017 (a), the dependence of the abundance (b) and the biomass of zooplankton (c) on temperature in 2015 and 2017

In 2017, not only the temperature range in the investigated water area was somewhat narrower, but the distribution also looked more homogeneous than in the data of 2015. The majority of the stations of the research, except one, were in the temperature range $23-26^{\circ} \mathrm{C}$.

The distribution of zooplankton abundance indices, unlike phytoplankton, did not follow unambiguously up the distribution of temperature value (Figure 18a). However, in general, the abundance of zooplankton (2015) decreased quite naturally with an increase in temperature (Figure 17b), although the two levels can be distinguished: up to $25^{\circ} \mathrm{C}$, where the highest values were noted, and higher, where the abundance almost did not change. For zooplankton biomass values in the temperature gradient (Figure $17 \mathrm{c})$, an increase in biomass in the range $25-29^{\circ} \mathrm{C}$ has been noted.

According to 2017 data, the distribution of abundance and biomass in the temperature gradient did not show any clear patterns of change (Figure $17 \mathrm{~b}, \mathrm{c})$, and was associated, rather, with local specific conditions in the pond. 

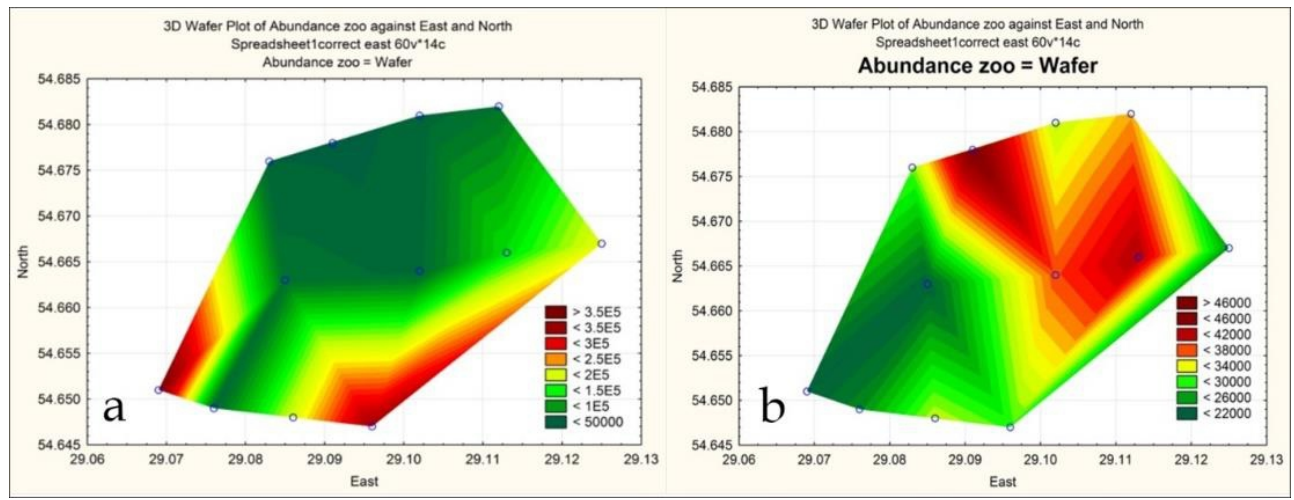

Figure 18. Distribution of zooplankton abundance in three transects in 2015 (a) and in 2017 (b) in the Lukomskoye Lake

However, with a large heterogeneity of the general zooplankton variables (2017), the distribution of individual taxonomic groups was more closely related to temperature (Figure 19).

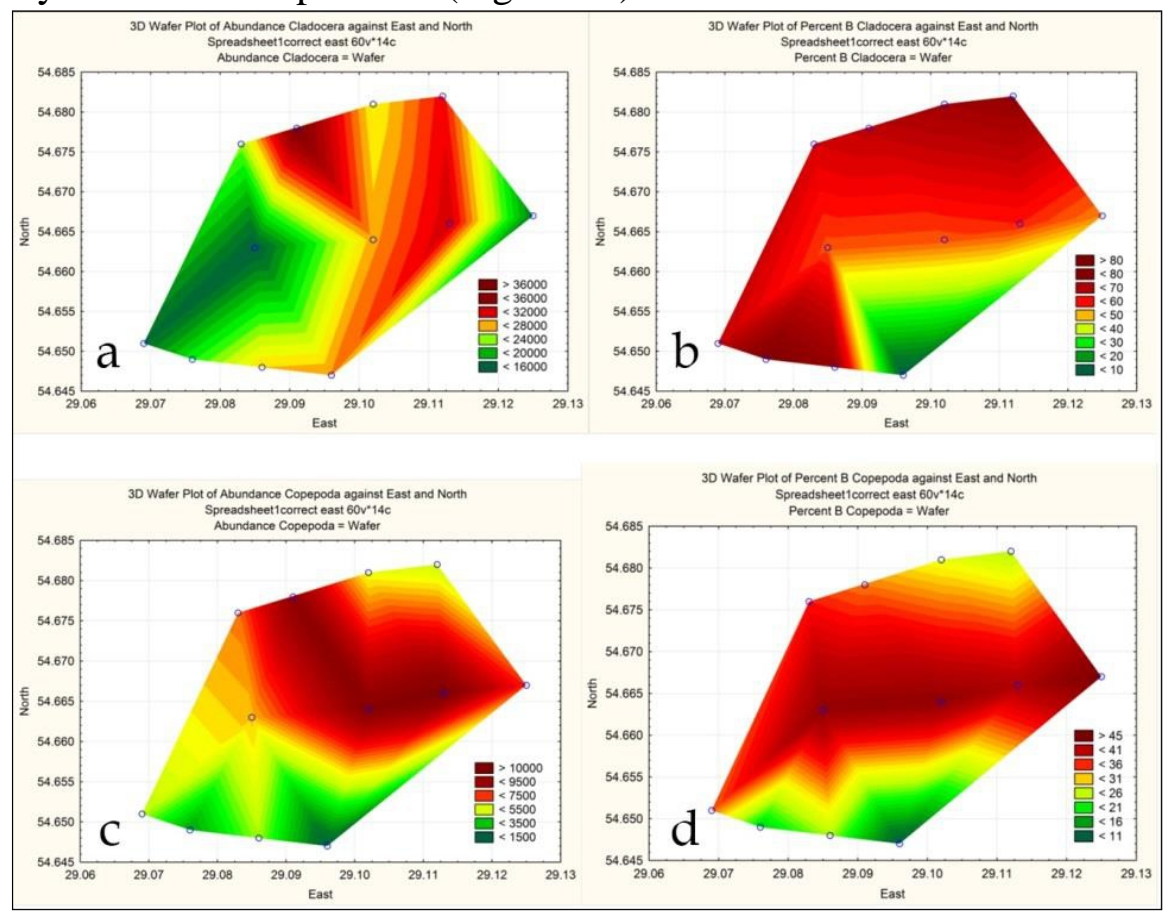

Figure 19. Distribution of abundance (a) and biomass (b) of Cladocera, as well as abundance (c) and biomass (d) of Copepoda in three transects in the Lukomskoye Lake in 2017.

\section{Discussion}

The terrestrial landscapes are highly heterogeneous, and the lake ecosystems are also heterogeneous in their spatial aspect, because they are associated with multidirectional and differently influenced environmental and 
climate factors (Kratz et al., 2005). The most sensitive to external influences link in the lakes is phytoplankton, as the first trophic level. Algal beta diversity reflects the highest rate of energy turnover in an ecosystem and demonstrates high heterogeneity in space and time (Maloufiet al, 2016). In addition to hydrochemical and hydrophysical environmental factors directly acting on plankton, there are also indirect effects, such as wind exposure and lake level fluctuations (Kratz et al., 2005; Nicol et al., 2013). The anthropogenically impacted lakes can be compared to the model natural lakes if only one factor is critical to the ecosystem like water temperature (Allan et al., 2016). In analysis of complex of influencing factors can help distance monitoring of the lake surface in which the phytoplankton sustainability is reflected (Allan et al., 2016).

It was established in the last years' research of different lakes that remote sensing of surface water temperature using satellite-based thermal infrared sensors can be accurate to fractions of a Celsius degree $\left({ }^{\circ} \mathrm{C}\right.$ ) (Allan et al., 2016). The experimental data was confirming high correlation between measured surface water temperatures and validated using a high-frequency sensor data. It gives us the way for comparing of ecological data mapping and the water temperature distribution maps which were constructed by two different methods from direct measurements of water temperature maps (Figures 4, 8), and remote sensing maps. So, the remote sensing maps can be used for approximately interpretation of biological parameters distribution in the cooling pools.

Earlier (Viktorov, 1986, Protasov, 2008), the Shannon-Boltzmann entropy function was used to quantify the variety of environmental conditions likes landscape diversity. We calculated a variety of temperature conditions for the KhNPP cooling pond.

Field studies have shown that the discharge of heated waters has a significant effect on the hydrothermal regime of the Lukomskoye Lake. For example, such an effect can be traced in terms of the thickness of ice on the lake (Mitrahovich et al., 2008). In 1975, there was practically no ice at a distance of about $1 \mathrm{~km}$ from the power plant, while in the southern part of the lake its thickness reached $50 \mathrm{~cm}$. The vertical temperature gradient in the heating zone can reach $6^{\circ} \mathrm{m}^{-1}$.

Our studies in KhNPP cooling pond have shown that, with a wind speed of about $3 \mathrm{~m} \mathrm{~s}^{-1}$, the phytoplankton of the technogenic flow from the discharge channel to intake one as well as of the circulation gyres, regardless of their direction and location, is characterized by a smaller range of fluctuations in biomass value than the phytoplankton of isolated, detached parts of the reservoir (Novoselova et al., 2015; Novoselova, Protasov, 2016).

With a sufficiently large heterogeneity of the values of the algoindex, its distribution corresponded to satellite derived of 3-D hydrodynamic model 
(Allan et al., 2016). In conditions of similar hydrodynamics and wind situation August, 29, 2012 in addition to the technogenic flow, a western anticyclonic circulation formed in the KhNPP cooling pond (Novoselova et al., 2015).

In the spatial aspect, the differences in the distribution of zoobenthos biomass in the KhNPP cooling pond were quite significant. Before the invasion of zebra mussels in 1998-2001 (Protasov, 2011), the minimum biomass was in the central region $\left(1.34 \mathrm{~g} \mathrm{~m}^{-2}\right)$; in other regions this variable was 11-37 times higher. So, the invasion of zebra mussel, a powerful edificator, further increased the heterogeneity of the distribution of indicators of the abundance of zoobenthos in the water area. In some areas, biomass differed by a thousand times in relation to the minimum values. The heterogeneity of the distribution of zoobenthos reflects the rather high coefficient of variation, which could reach $240 \%$ or more.

The use of distance sensing methods in relation to the inspection of the profundal part of water bodies is limited. However, these methods in relation to zoobenthos can be used in assessing and predicting the processes of transformation of zoobenthos in conditions of unstable water level, possible changes in shallow areas of water bodies, in planning measures to reduce the negative consequences of lowering water levels and drainage (Tomchenko et al., 2017; Protasov A. A. et al., 2018).

The decrease in the water level of KhNPP cooling pond in 2015 led to the death of a significant number of bivalve mollusks - Dreissenid and Unionidae. For example, according to research in 2009 (Protasov, 2011), the stock of bivalve mollusks at a depth of $2 \mathrm{~m}$ was more than 500 tons. When benthic organisms die on drained sites, the rapid flow of large amounts of organic matter can lead to deterioration in the quality of the environment throughout the reservoir.

Transparency of water in KhNPP cooling pond depends on phytoplankton biomass (Protasov, Novoselova, 2015; Novoselova, Protasov, 2015), and biomass and abundance, in turn, depend on temperature. The distribution of the extremums of values had rather a circular character. So, for green algae, as well as for diatoms, the average transect was the zone of their maximum share in the total biomass. As shown by years of research (Mitrahovich et al., 2008), the level of phytoplankton development during the growing season was higher in the zone with a temperature regime close to natural.

It should be noted a certain heterogeneity of phytoplankton in time. In the beginning 1970s at the initial stage of zebra mussel (Dreissena polymorpha Pall.) invasion, the trophic status of the KhNPP cooling pond ecosystem was characterized as eutrophic. Then, the abundance of algae, against a background of technogenic rise in temperature, dropped sharply and remained low until the end of the 1970s. Since the 1990s, the intensity of algae 
development has increased, and cyanobacteria caused a "flowering" of water (Mitrahovich et al., 2008).

According to (Barinova et al., 2017a,b; Protasov et al., 2017b) it was noted that environmental and biotic variables in the KhNPP cooling pond varied in time and space. Long-term changes were associated with an increase in NPP capacity and the introduction of a mollusk filter feeder Dreissena polymorpha Pallas (Barinova et al., 2017b; Novoselova, Protasov, 2015).

Spatial changes are mainly determined by the dynamic hydrodynamic conditions in the reservoirs and the presence of technogenic flow of cooling water. As studies have shown in KhNPP cooling pond the distribution of quantitative indicators of zooplankton in the surface layer was largely determined by the position of individual sections of the reservoir relative to technogenic and wind circulation flows, more than by thermal conditions (Gromova, Protasov, 2017a,b).

As in earlier studies (Barinova et al., 2017a), the distribution of phytoplankton variables in the pelagic zone of the KhNPP cooling pond was very heterogeneous. The population structure, like its level, was determined by cyanobacteria, and biomass - by diatoms. The southern region, which receives the flow of the Gniloy Rog River and, with the east wind, is practically not involved in cooling the circulation flow, differed significantly in composition and abundance of phytoplankton from other areas of the reservoir. During the meteorological situation that developed during the period of our research, the flow of water from the outgoing channel to the inlet was stretched over most of the water area. The phytoplankton biomass carried by the stream gradually increased in the direction of water movement. The structure of abundance, as well as its level was determined by cyanobacteria, in contrary the biomass controlled by diatoms. The dynamic distribution of temperature fields under the influence of currents in the pelagic part of the reservoir created the conditions for the existence of species indifferent to temperature.

\section{Conclusion}

Remote sensing provides a unique opportunity to explore the heterogeneity of the distribution of thermal conditions in water bodies, which is especially important for techno-ecosystems of nuclear power plants and thermal power plants. Point measurements do not give a complete picture. However, using the construction the series of statistically generated wafer plots of environmental and biological variables distribution over the pond surface can be modeled conditions of heterogeneity. This makes it possible to compare the heterogeneity of environmental conditions and the heterogeneity of the distribution of biotic indicators. Studies on water bodies conducted in situ in parallel with remote sensing gave a unique opportunity mutually add 
the results obtained by these methods, in particular using build of plots of distribution of indicators.

Hydrological conditions in reservoirs-coolers of thermal power plants and nuclear power plants are characterized by great dynamism. Depending on the mode of operation of the plant, and the meteorological situation in the reservoir is formed by the different power and direction of the currents and gyres. The use of digital remote sensing maps of the earth made it possible to confirm, in general terms, the correctness of the current models of currents in the KhNPP cooling pond. The habitats of hydrobionts were distinguished by high diversity.

In the lake Lukomskoye influence of technogenic factors on the distribution of plankton was less pronounced, since the technogenic circulation practically did not cover the whole water area. Nevertheless, it was possible to establish some features of the distribution of the numbers of algae and crustaceans in different thermal zones.

So, this doing first time research unlocks the potential of remote sensing for monitoring temporal and spatial trends with using of ecological mapping, which may prove useful for analysis of climate change effects on lakes with power plants impact.

\section{Acknowledgements}

The work was supported by the Ministry of Education and Science of Ukraine, Ukraine-Belarus Collaboration Project No. M/22-2018, and the "Program of Development of Priority Scientific Research directions of the National Academy of Sciences of Ukraine for 2018, Byelarus Foundation of Fundamental Researches (BRFFR NoB17 UKRG-004), and partly by the Ministry of Aliyah and Integration of Israel.

\section{References:}

1. Allan, M.G., Hamilton, D.P., Trolle, D., Muraoka, K., McBride, C. (2016). Spatial heterogeneity in geothermally-influenced lakes derived from atmospherically corrected Landsat thermal imagery and threedimensional hydrodynamic modelling. International Journal of Applied Earth Observation and Geoinformation, 50, 106-116. https://doi.org/10.1016/j.jag.2016.03.006.

2. Barinova, S. (2017). Ecological Mapping in Application to Aquatic Ecosystems BioIndication: Problems and Methods. International Journal of Environmental Sciences \& Natural Resources, 3(2), 1-7, DOI: 10.19080/IJESNR.2017.03.555608.

3. Barinova, S.S., Krupa, E.G., Protasov, A.A., Novoselova, T.N. (2017b). Benthification in the Inland Water Ecosystems of Eurasia, 
some Ecological Aspects. MOJ Ecology \& Environmental Sciences, 2(7), 00048, DOI: 10.15406/mojes.2017.02.00048

4. Barinova, S.S., Protasov, A.A., Novoselova, T.N. (2017a). Spatial Analysis of Environmental and Biological Variables in the TechnoEcosystem of the Khmelnitsky Nuclear Power Plant with New Statistical Approach. MOJ Ecology \& Environmental Sciences, 2(3), $1-7$.

5. Gromova, Yu.F., Protasov, A.A. (2017a). The Long-term Dynamics and Distribution of Dreissena Veligers in the Cooling Pond of the Khmelnytsk NPP and Their Role in Zooplankton Structure. Hydrobiological Journal, 53(1), 3-16.

6. Gromova, Yu.F., Protasov, A.A. (2017b). Spatial Heterogeneity of Zooplankton in the Water Bodies of the Khmelnytsk NPP Technoecosystem. Hydrobiological Journal, 53(6), 12-25.

7. Guiry, M.D., Guiry, G.M. (2018). AlgaeBase. World-wide electronic publication. National University of Ireland, Galway. http://www.algaebase.org; searched on 22 October 2018.

8. Kiselev, I.A. (1980). Plankton of the seas and continental waters. V. 2. Distribution, seasonal dynamics, nutrition and value. Leningrad: Science. [In Russian]

9. Kratz, T.K., MacIntyre, S., Webster, K.E. (2005). Causes and Consequences of Spatial Heterogeneity in Lakes. In: Lovett, G.M., Turner, M.G., Jones, C.G., Weathers, K.C. (eds), Ecosystem Function in Heterogeneous Landscapes. New York: Springer, 329-347. https://doi.org/10.1007/0-387-24091-8_16

10. Kumsare, A.Ya. (1963). Calculation of biomass of phytoplankton in the total volume of cells. Fishery in the Latvian SSR. Riga: Zinatne, 7, 67-73. [In Russian]

11. Kuzmin, G.V. (1975). Phytoplankton. Methodology for studying biogeocenoses of inland water bodies. Moscow: Science, 73-78. [In Russian]

12. Maloufi, S., Catherine, A., Mouillot, D., Louvard, C., Couté, A., Bernard, C., Troussellier, M. (2016). Environmental heterogeneity among lakes promotes hyper $\beta$-diversity across phytoplankton communities. Freshwater Biology, 616 633-645. doi:10.1111/fwb.12731

13. Methodology of hydroecological surveys of surface waters. (2006). Kyiv: Logos. [In Ukrainian]

14. Mitrahovich, P.A. et al. (2008). The ecosystem of the cooling pond of the Lukoml SDPP. Minsk: Law and Economics. [In Russian]

15. Nicol, S., Roach, J.K., Griffith, B. (2013). Spatial heterogeneity in statistical power to detect changes in lake area in Alaskan National 
Wildlife Refuges. Landscape Ecology, 28(3), 507-517. https://doi.org/10.1007/s10980-013-9853-5

16. Novoselova, T.M., Protasov, O.O. (2016). Features of phytoplankton techno-ecosystems of power plant (for example, Khmelnitsky NPP). Botany and mycology: Modern Horizons. Kyiv: 344-367. [In Ukrainian]

17. Novoselova, T.N., Gromova, Yu.F., Protasov, A.A. (2015). Spatial heterogeneity of plankton in the NPP techno-ecosystem. Scientific notes of the Ternopil National Peduniversitet the name of V. Gnatyuk. Ser. Biologia, Special issue: Hydroecology, 3-4(64), 506-509. [In Russian]

18. Novoselova, T.N., Protasov, A.A. (2015). Phytoplankton of cooling ponds of techno-ecosystems of nuclear and thermal power plants (a review). Hydrobiological Journal, 51(2), 37-52.

19. Pesenko, Yu.A. (1982). Principles and methods of quantitative analysis in faunistic studies. Moscow: Science. [In Russian]

20. Plokhinsky, N.A. (1970). Biometrics. Moscow: Moscow University Press. [In Russian]

21. Protasov, A.A. (2013). On water techno-ecosystems and their place in the biosphere. Journal of Siberian Federal University. Biology, 4(6), 405-423. [In Russian]

22. Protasov, A.A. (2014). Concept of Techno-Ecosystem in Technical Hydrobiology. Hydrobiological Journal, 50(5), 3-15.

23. Protasov, A.A. (Ed.). (2011). Techno-ecosystem of NPP. Hydrobiology, environment, and ecological assessment. Kiev: Institute of Hydrobiology NASU. [in Russian].

24. Protasov, A.A. (2008). Biodiversity and its assessment. Conceptual diversicology. Kiev: National Academy of Sciences of Ukraine, Institute of Hydrobiology [in Russian].

25. Protasov, A.A. et al. (2018). The use of ground and space methods in the investigation of in homogeneities of the spatial structure of biotic and abiotic components of the water techno-ecosystem of a nuclear power plant. Transboundary cooperation in the field of environmental safety and environmental protection. Proceed. IV International scientific practice Conf. (June 4-5, 2018, Gomel). Gomel, 458-462. [In Russian]

26. Protasov, A.A., Barinova, S.S., Novoselova, T.N. (2017b). Characteristics of the Ecological State of a Cooling Pond of a Nuclear Power Station Based on Bioindication Indices of Phytoplankton. Hydrobiological Journal, 53(4), 3-21.

27. Protasov, A.A., Novoselova, T.N. (2015). Interrelationship between indicators of water transparency and the development of plankton 
algae in a Khmelnitsky NPP cooling pond. Nuclear energy and the environment, 1(5), 50-52. [In Russian]

28. Protasov, A.A., Silaeva, A.A., Novoselova, T.N., Gromova, Yu.F., Morozovskaya, I.A., Stepanova, T.I. (2017a). NPP Techno-ecosystem: 18 Years of Hydrobiological Observations. Journal of Siberian Federal University. Biology, 10(4), 459-484. [In Russian]

29. Protasov, A.A., Sinitsina, O.O., Kolomiets, A.V. (1999). Use of the WaCo (Water Communities) package to process the hidrobiological samples and create the databases on zoology and algology (FoxPro). Proceedings of Institute of Zoology of RAS, St-Petersburg, 278: 132.

30. Shcherbak, V.I. (2006). Methods of research of phytoplankton. Methodological bases of hydrobiological researches of aquatic ecosystems. Kyiv: without publisher, 41-47. [In Ukrainian]

31. Silkin, K.Yu. (2012). Methodology of assessing the ecological status of the Voronezh reservoir based on materials of multi-zone remote sensing. Vestnik VSU, Ser. Geology, (1), 220-223. [In Russian]

32. Smirnov, E.S. (1969). Taxonomic analysis. Moscow: Moscow University Press. [In Russian]

33. Tang, H., Li, Z.-L. (2014). Quantitative remote sensing in thermal infrared: theory and applications. Berlin: Springer-Verlag.

34. Timchenko, V.M., Timchenko, O.V., Gulyayeva, O.A. (2014). Ecological-hydrodynamic characteristics of the cooling pond of Khmelnitsky NPP. Nuclear power and the environment, 1(3), 39-43. [In Russian]

35. Tomchenko, O.V., Silayeva, A.A., Protasov, O.O. (2017). Use of space observation data from the earth's surface to assess the transformation of the littoral zone of the cooling pond provided that water levels are reduced. Pure water. Fundamental, Applied and Industrial Aspects. Proceed. V Intern. Scientific and Technical Conf. (October 26-27, 2017, Kyiv). Kyiv, 207-209. [In Ukrainian]

36. Topachevsky, A.V., Masyuk, N.P. (1984). Freshwater algae of the Ukrainian SSR. Kyiv: High school. [In Russian]

37. Townsend, C.R. (1989). The patch dynamics concept of stream community ecology. J. North. Amer. Benthol. Soc., 8(1), 36-50.

38. Viktorov, A.S. (1986). Picture of landscape. Moscow: Mysl. [In Russian]

39. Zhirkov, I.A. (with the participation of A. I. Azovskiy and O. V. Maksimova). (2010). Life at the bottom. Bio-geography and bioecology of benthos. Moscow: Company scientific publications KMK. [In Russian] 